\title{
Voluntary Associations Within the Local Political Context: How Characteristics of the Organizations and the Local Governments Influence Perceptions of Success
}

\author{
Susanne Wallman Lundåsen
}

Published online: 18 June 2013

(C) International Society for Third-Sector Research and The Johns Hopkins University 2013

\begin{abstract}
A cornerstone of democracy is the capacity of citizens to influence political decisions either through elections or by making their will known in the periods between elections. The aim of the present study is twofold: (1) to explore what factors inherent of the voluntary associations that determine the perceived success in their attempts to influence policy and (2) to investigate what role the composition of the local government have on the perceived success. This study is based on a survey conducted among 404 local voluntary associations in four different municipalities in Sweden. The results show that the frequency contacts influence perceived success positively, while the level of civic engagement of the voluntary associations affected the perceived success negatively. Having a heterogeneous local government also contributed positively to the perceived success to influence policy.
\end{abstract}

Résumé Un des éléments essentiels de la démocratie est la capacité des citoyens à influencer les décisions politiques soit par le biais d'élections, soit en faisant connaître leur volonté entre les périodes d'élection. Le but de cette étude est double : (1) explorer les facteurs qui, inhérents aux associations bénévoles, déterminent le succès perçu de leurs tentatives d'influencer les politiques et (2) chercher à établir le rôle que la composition du gouvernement local semble avoir quant à la perception de ce succès. Cette étude est fondée sur une enquête conduite auprès de 404 associations bénévoles locales dans quatre municipalités suédoises. Les résultats montrent que la fréquence des contacts influence la perception du succès de façon positive, alors que le niveau d'engagement civique des associations bénévoles affecte la perception du succès de façon négative. L'hétérogénéité du gouvernement local contribue aussi de façon positive à la perception du succès des efforts pour influencer les politiques.

S. Wallman Lundåsen $(\bowtie)$

Ersta Sköndal University College, Stockholm, Sweden

e-mail: susanne.wallman-lundasen@esh.se 
Zusammenfassung Ein Grundstein der Demokratie ist die Fähigkeit der Bürger, politische Entscheidungen entweder durch Wahlen beeinflussen oder ihren Willen zwischen den Wahlen bekannt machen zu können. Die vorliegende Studie hat zwei Ziele: (1) Es soll untersucht werden, welche immanenten Faktoren der gemeinnützigen Verbände den wahrgenommenen Erfolg bei der Beeinflussung der Politik seitens der Bürger bestimmen und (2) welche Rolle der Aufbau der Lokalregierung bei dem wahrgenommenen Erfolg spielt. Die Studie beruht auf einer Befragung von 404 lokalen Wohltätigkeitsverbänden in vier verschiedenen Gemeinden in Schweden. Die Ergebnisse zeigen, dass sich die Kontakthäufigkeit positiv auf den wahrgenommenen Erfolg auswirkt, während das Ausmaß des Bürgerengagements der Wohltätigkeitsverbände den wahrgenommenen Erfolg negativ beeinflussten. Eine heterogene Lokalregierung trug positiv zu dem wahrgenommenen Erfolg bei der Politikbeeinflussung bei.

Resumen Una piedra angular de la democracia es la capacidad de los ciudadanos de influir en las decisiones políticas mediante las elecciones o dando a conocer su voluntad en los períodos entre elecciones. El objetivo del presente estudio es doble: (1) explorar qué factores inherentes a las asociaciones de voluntarios determinan el éxito percibido en sus intentos de influir en la política y (2) investigar qué papel tiene la composición del gobierno local en el éxito percibido. El presente estudio se basa en una encuesta realizada entre 404 asociaciones de voluntarios en cuatro municipios diferentes en Suecia. Los resultados muestran que la frecuencia de los contactos influye en el éxito percibido de manera positiva, mientras que el nivel de compromiso cívico de las asociaciones de voluntarios afectaba al éxito percibido de manera negativa. Tener un gobierno local heterogéneo también contribuía de manera positiva al éxito percibido de influir en la política.

Keywords Political participation - Voluntary associations - Local government · Municipalities · Contacts · Influence

\section{Introduction}

A cornerstone of democracy is the capacity of citizens to influence political decisions either through elections or by making their will known in the periods between elections. The expression of the will of a group of citizens through an organization may improve their likelihood of successfully influencing policymakers' decisions. Previous studies have asserted the importance of civil society organizations in both shaping the processes of policymaking and shaping the political culture of a community (Almond and Verba 1963; Putnam 1993; Knoke 2009). Within the theoretical framework of a responsive democracy, it is important that citizens participate between elections by expressing their demands for policy changes to improve the representation of their interests (Verba and Nie 1972, 1987).

Since the writings of Alexis de Tocqueville, the role of associations in democracy has been the subject of debate and investigation. The renewed interest in civil society organizations that came from social capital literature has resulted in a focus 
on whether the type of association matters for the democratic process at large and for the behavior of members or others engaged within the association (Putnam 1993, 2000; Teorell 2003; Stolle 2001; Quintelier 2008; van der Meer and van Ingen 2009; Paxton 2002, 2007).

At the same time, there has been an academic debate concerning a putative change in the character of civil society organizations in both Europe and America (Zald and Ash 1966; Skocpol 2003; Young 2002). Social scientists are concerned about whether civil society organizations are becoming less involved in the policy process because it may threaten the base of civic engagement upon which democracies rest (Skocpol 2003). Active participation by members is argued to increase members' civic skills and institutionalize democratic forms of collective action (cf. Verba et al. 1995; Wollebæk and Strømsnes 2008).

Recent analyses based on empirical case studies in the Swedish context have found simultaneous and contrasting trends of how civil society organizations take part in the policy process at different levels (Amnå 2005; Lundberg 2012; Munk Christiansen et al. 2010; Harding 2012; Einarsson 2012). However, most studies have tended to focus on the participation of civil society organizations in the national level policy process and less attention has been paid to the local political arena.

Whether and how local voluntary associations without apparent political scope, such as leisure associations, act in the local political arena and what determines their perceptions of success have been the subject of relatively few quantitative studies. This study will contribute with a quantitative study that maps opinions and reported behaviors of more than 400 local voluntary associations and an investigation of how factors related to both the voluntary associations and factors related to the local governments have an impact on how voluntary associations perceive they can influence policy.

The aims of the present study are therefore twofold: (1) to explore whether and to what extent local voluntary associations contact local politicians in an attempt to influence them, and to what extent factors inherent to the local voluntary associations contribute to the perceived success of their attempts to influence policy, and (2) to investigate to what extent factors inherent of the local government determine the perceptions of success of the local voluntary associations. This study is based on a survey conducted among 404 local voluntary associations in four different municipalities in Sweden. In what follows, the theoretical framework is presented.

\section{The Importance of the Institutional Context}

A question within the studies of the political participation of voluntary associations is whether the participation is limited to certain types of organization, such as interest groups and activist organizations, or whether this behavior is even adopted by leisure organizations (cf. Putnam 1993; van der Meer and van Ingen 2009).

Several studies have investigated the role of civil society at the local level (Schulz and Bailer 2012; Öberg and Svensson 2012; Varda 2012). Studies have also 
underlined the importance of the political context when analyzing the consequences of civic engagement and have shown that the attitudes of local political elites influence how citizens' activities are received (Oxendine et al. 2007). A study using Swedish data found that local politicians' attitudes toward citizens' protests depend on whether they are in power or not, with politicians in opposition being significantly more positive toward such protests (Gilljam et al. 2012). The impact of the attitudes and behaviors of political leaders may have an enduring effect on the activities of civil society organizations (Oxendine et al. 2007). Other local-level studies have been carried out in the European context, investigating the role played by voluntary associations in local politics (Maloney and Van Deth 2010; Schulz and Bailer 2012). The extent to which volunteers are politically mobilized and become civically engaged appears to be related to the local political context rather than features of the voluntary associations themselves (Schulz 2010).

In the Swedish case, several historical studies have repeatedly confirmed that, traditionally, local voluntary associations most frequently participated in local politics by attempting to influence public opinion and through contacts with politicians (Back 1967; Lundkvist 1977; Micheletti 1995). The pattern of using contacts at the local level as a means of influencing politics was established early. Historical studies have described how direct contacts between voluntary associations and politicians had already developed prior to the introduction of universal suffrage (Back 1967; Lundkvist 1977; Trägårdh and Rothstein 2007). Studies also have described that the local voluntary associations tended to resemble each other both in terms of formal organizational structure and how to influence policy, quite independently of their scope (Lundkvist 1977). The voice function of organizations is argued to have been encouraged in countries with institutional contexts similar to Sweden's (Lundström and Svedberg 2003; Salamon and Anheier 1998). A quote from Salamon and Anheier (1998: 242) summarizes the characteristics of Sweden, "[...] where a very substantial network of volunteer-based advocacy, recreational and hobby organizations turns out to exist alongside a highly developed welfare state."

In line with the studies described above, we can hypothesize that the type of activity that the voluntary associations carry out is of less importance than the institutional setting (e.g., Maloney and van Deth 2010; Schulz 2010; Lundkvist 1977).

H1 Voluntary associations will tend to resemble each other, independent of activity, in terms of their pattern of trying to influence policy within the same institutional setting.

\section{Putting Local Voluntary Associations into the Context of a Responsive Democracy}

An important delineation within normative democratic theory is between elitist models that emphasize only the political process that occurs during elections between the political parties and those models that regard the political system more 
broadly, including the ways in which citizens attempt to make the political system "respond to their will" (Teorell 2006: 789). Studies of so-called off-election democracy focus on the attempts by various interest groups and citizens to influence policy outcomes (cf. Munk Christiansen et al. 2010).

In their seminal contributions, Verba and Nie $(1972,1987)$ delineate a model for a responsive democracy. They support a more inclusive form of democracy in which citizens and civil society organizations take part in the political process and attempt to influence government decisions at any level of the political system (Verba and Nie 1987). They also draw the broad conclusion that greater political participation in society leads to a greater concurrence between political agendas and public opinion (Verba and Nie 1987). The level of responsiveness of political elites is influenced by factors such as the general degree of differences in opinion between elites and citizens. Contact initiated by citizens or their organizations provides information about citizens' demands for policy outcomes, and political elites may respond to this contact in a variety of ways. If the general difference between political elites and citizens is small, substantial citizen participation increases the pressure on the elites to deliver the requested policy outcomes. In contrast, if the differences in opinion between the citizens and elites are great, citizen participation between elections may actually increase the distance between the elites and public opinion (Verba and Nie 1987). The policy process as conceived by Verba and Nie (1987: 50) does not merely address important political decisions that have a broader impact on society, but also addresses those seemingly narrower decisions about how to allocate resources at the local level. All of these, even the small issues, are components of the policy process. Furthermore, considering all of the small and seemingly narrow decisions together means that even small distortions in individual decisions may result in great distortions-if a systematic bias exists- to which political elites respond. Additionally, Verba and Nie (1987) recognize that the purpose of participation may not always be the individuals' or organizations' altruism or their desire to improve society at large. Regardless, apparently nonaltruistic motives for participation may still lead to consequences that improve policies for the general public (Verba and Nie 1987).

Wohlgemuth (2006) used the theoretical framework elaborated by Verba and Nie to investigate the extent to which citizens' participation affects the responsiveness of local political elites and whether the density of voluntary associations (the number of voluntary associations per capita) has an impact on differences between the opinions of the local political elites and citizens in local communities. He (Wohlgemuth 2006) concluded that the concurrence between local political elites and citizens is greater in local communities with more voluntary associations per capita. Wohlgemuth (2006) also found that the policy process within the Swedish municipalities tends to resemble responsive democracy, as citizens attempt to influence policy outcomes by actively contacting politicians. Even though the study by Wohlgemuth (2006) did not map or investigate exactly how the voluntary associations interacted with the local political elite, it was assumed that there was a higher degree of contacts or overlapping social networks in communities with a high density of voluntary associations, which, in turn, would lead to more information about the general will of the citizens reaching the local elites. A similar critique was 
directed toward the study of Italy by Putnam (1993), which lacked a proper description of the causal mechanisms linking the social capital created within the voluntary associations to the political institutions (cf. Rothstein 2005).

Drawing upon the study by Verba and Nie (1987), it can be hypothesized that the amount and frequency of contacts will have an additive positive effect:

H2a The more often that voluntary associations contact local politicians, the more likely they are to perceive that they are being successful.

H2b The greater variety of types of elites that voluntary associations contact, the more likely they are to perceive that they are being successful.

The following sections present theoretical arguments about how factors related to the local political elites and factors related to the associations may determine the system's perceived responsiveness.

\section{The Homogeneity or Heterogeneity of Local Political Elites}

The literature regarding social movements discusses how institutional characteristics, such as the relative openness of the political system and the heterogeneity or homogeneity of political elites, affect the behavior of organizations vis-à-vis the political system. What factors facilitate or render it more difficult for organizations to exercise influence at the local level? The literature on social movements is helpful in understanding what factors may influence the outcome of attempts to influence policy as it has also elaborated the concept of political opportunity structures (e.g., Kitschelt 1986; Tarrow 1998). The voluntary organizations studied here are more institutionalized than the social movements, but the elements influencing their own perceptions of their roles in the local political arena may to some extent be similar. Moreover, the difference between voluntary associations and social movements can be regarded as a difference in the degree of organizational institutionalization rather than as a difference in kind. It has been argued that social movements constitute the first phase in the process of becoming more stable organizations and that many voluntary associations began as social movements or more loosely formed networks (Ahrne and Papakostas, 2006). However, different from most social movements, it is also reasonable to assume that most local voluntary associations are engaged in local issues that in general do not provoke strong conflicts and few have an ambition to challenge the existing system.

If political opportunities are also conceptualized as perceived opportunities, then it is also relevant to study the perceptions of the actors, as Tarrow (1998) has noted and in this case the study concerns the perceived success of the local voluntary associations.

Political opportunity structures have been defined in several different ways, making it difficult to compare the results between studies (Morales 2009). However, according to Morales (2009), some agreement exists on the basic elements that define political opportunity structures, which include the following: formal institutional arrangements, informal processes within the institutions, the alliance 
opportunities that organizations encounter, and the fragmentation of political elites (Morales 2009: 167; McAdam 1996; Rochon 1998). The formal institutional arrangements are uniform in the present study as it involves comparisons within the same country. The alliance opportunities often refer to the levels of corporatism at a national level, which also are uniform. However, the local communities differ in terms of their local governments. When political elites are fragmented, the centrifugal behavior of the different actors within the elite group tends to increase. In governments composed of coalitions, there is an element of competition between the parties in the coalition, who aim to strengthen their own positions within the government (Morales 2009). One way to strengthen a party's position is to accommodate the demands advanced by different societal groups in order (to appear) to be aligned with public opinion (Morales 2009). Fragmentation may thus increase the opportunity for external actors, such as voluntary organizations, to influence the outcomes of political decisions.

Furthermore, given theories about the homogeneity or heterogeneity of political elites (Morales 2009), we can expect structural factors within local governments to affect the perceived responsiveness of local politicians. If the local government is composed of or dominated by a single political party, this characteristic would be expected to have a negative impact on the government's responsiveness. In contrast, if the local government is composed of a broader coalition, this quality will enhance the heterogeneity of the political elites and will also increase the chances of being successful due to the centrifugal behavior of political parties within coalitions. Therefore, the following hypothesis can be formulated:

H3 Voluntary associations are more likely to perceive success in their contacts with local politicians if the local government is composed of a coalition.

The following section elaborates on the importance of certain factors related to the voluntary associations for their perceptions of success.

\section{Characteristics of Voluntary Associations and Political Influence}

Characteristics of the voluntary associations have been proved to be relevant for their ability to influence policy (Elvander 1968). The size of an organization, in terms of the number of members, has been shown to be related to its capacity to influence political decisions (Feltenius 2004; Elvander 1968). A large organization can influence the political process by threatening to engage in public criticism of political leaders or to sway public opinion against the political leadership. Influence can be exercised using the sheer number of members as potential or real indicators of power. The number of members could be used in the debate as potential voters that are requesting a policy change and the more members that an association has the more pressing its demands may seem for the political leaders (cf. Feltenius 2004).

From previous studies (Feltenius 2004; Elvander 1968), we may assume that the size of voluntary associations can have an impact on their perceptions of politicians' responsiveness, as the number of members is related to the power of a voluntary association and therefore the following hypothesis can be formulated: 
H4 The more members voluntary associations have, the more likely it is that they will perceive their contacts with local politicians to be successful.

Another factor brought forward in previous studies of the civic engagement of local voluntary associations is the strength or intensity of engagement and that this intense engagement may not correlate positively with their own perceptions of success (Nilsson 2005). Highly engaged groups may become more dissatisfied with politics. Associations may become discouraged as they confront the workings of the political system. This disillusionment can occur because the members of these engaged voluntary associations do not always realize that politicians govern limited resources and must prioritize different groups (Nilsson 2005; Lindberg 2005; Christensen and Aars 2011). Sometimes, frustration arises from confronting what is perceived as the slow workings of formal political decision-making procedures. Alternatively, engagement itself may deepen and broaden the organization's understanding of what changes are necessary. In other words, engagement may open members' eyes to an array of different and more complex issues to be resolved (cf. Nilsson 2005). Even if a solution is found to the initial question that was raised, this resolution may not create feelings of success if the members have become aware of other problems that need to be solved. Christensen and Aars (2011) found that a high density of voluntary associations tends to correlate negatively with the evaluation of local politicians, and they hypothesized that municipalities with many voluntary associations per capita tend to place local politicians under more pressure and subject them to a more openly critical public debate. This openly critical public debate may in turn lead to a more negative opinion of the local politicians (Christensen and Aars 2011).

As mentioned above previous studies (Nilsson 2005; Christensen and Aars 2011) have also found that civic engagement among local voluntary associations does not always equal feelings of success, with more engagement often bringing more discontent. The following hypothesis can be formulated:

H5 The stronger voluntary associations value civic engagement, the less they will perceive that they are successful in their contacts with local politicians.

The characteristics of the Swedish context will be described briefly in the following section, and the data and analyses will be presented thereafter.

\section{The Swedish Context}

Schofer and Fourcade-Gourinchas (2001:811-813) noted how institutional constraints affect the types of involvement in civil society that occur as well as the civic engagement that these civil society organizations will undertake. Sweden is characterized as having low degrees of centralization of political power (statism) and high degrees of incorporating social actors (corporateness). Although some observers have lamented a decline in civil society participation in general (Skocpol 2003), recent studies in Sweden indicate that this decline is not occurring. Citizens 
continue to be actively involved in Swedish civil society organizations (Statistics Sweden, 2011; Svedberg, von Essen and Jegermalm 2010).

Several political theorists have characterized the Swedish model of governance as focusing on consensus; notably, Lijphart (1999) described consensus-type democracies as being kinder and gentler. According to Lijphart (1999:293), these democracies have a strong community orientation and social consciousness. Sweden has been described as a political system that is relatively open to the influence of civil society organizations on the input side (Kitschelt 1986). Goodin (2010) (chapter 8) depicted the special character of the Scandinavian democracies as input democracies. Input democracies focus on the input side in the political process and in deliberative processes preceding decisions and attempt to create broad consensus rather than conflict (Goodin 2010). The focus within the specific institutional framework of input democracy is on moderating conflict by anticipating the interests of different groups. Civil society organizations have since long also participated in the policy process through committees and commissions that elaborate on legislative proposals (Munk Christiansen et al. 2010; Wallman Lundåsen 2012).

At the local level, the political process in Sweden is often characterized as more pragmatic and less ideological than the political process at the national level (Bäck et al. 2005). Historically, the municipalities were not governed by the political parties but by a system more resembling direct democracy. Bäck et al. (2005) have argued that there may be a return to a form of local democracy with less ideological influence by the political parties and with a stronger focus on practical issues related to the local communities. The existence of coalitions in local governments between political parties that oppose each other at the national level could be interpreted as an indicator of the more pragmatic orientation of local politics.

Municipalities also enjoy autonomy of decision over certain issues regulated by the constitution. Local governments handle most welfare services in Sweden, such as schools, childcare, and elderly care; therefore, they account for a larger share of the GDP than in any other country (Bäck et al. 2005). This fact makes local governments important subjects of study as political arenas. Municipalities also enjoy relative freedom to determine the nature of their relationships with local voluntary associations, as economic support to local voluntary associations is not regulated in the legislation that delineates the mandatory functions of municipalities. Therefore, whether and how municipalities wish to support voluntary associations directly or indirectly, for example, through infrastructural support, is open, as long as the municipalities adhere to the principle of equality.

The following section presents an outline of the empirical study upon which the present study is based and its results.

\section{Data and Methods}

This study is based on a survey carried out in four municipalities. The selection of municipalities was guided by theoretical factors that may enhance general civic engagement and the frequency of political contacts. Two equivalent pairs of 
municipalities were selected according to population size (two small and two average-sized municipalities). Previous studies have shown that the size of the local community has an important effect on the frequency of contact with local politicians (Johansson et al. 2007). The municipalities studied here displayed different forms of political leadership. One municipality was governed by a single-party majority, and the other three were governed by different sized coalitions. The municipalities varied in terms of the number of voluntary associations per capita (high and low) as the density of voluntary associations may have an impact on political participation (cf. Putnam 1993; Wollebæk and Strømsnes, 2008; Wohlgemuth 2006). Table 6 presents the criteria used to select the municipalities.

The survey questionnaire was sent out to all of the voluntary associations in the four municipalities that were present in the register of organizations kept by Statistics Sweden. At the time of the study, the register of organizations kept by Statistics Sweden offered the most complete listing of voluntary associations present in the municipalities. ${ }^{1}$ However, it is important to note that the operational definition of a voluntary association does not include the entire range of civil society organizations in Sweden, but rather accounts only for the most common form of civil society of organization.

Sweden lacks general legislation defining voluntary associations; instead, voluntary associations are defined in the tax regulations. The tax legislation distinguishes between voluntary associations and economic associations. A voluntary association consists of a group of members with not-for-profit activities and/or aims. The register of Statistics Sweden covers more than 120,000 voluntary associations. Voluntary associations in Sweden are generally small and primarily depend on the voluntary efforts of their members; therefore, they tend to have few economic resources (Lundström and Svedberg, 2003).

Political parties were excluded from this survey, as it is tautological to investigate the political contacts of a political party as political parties by definition have contacts with politicians. Other organizations that were excluded from the survey were organizations that had remained in the register but had de facto (selfreported) ceased their activities, associations for which the questionnaires were returned unanswered owing to incorrect addresses and associations that were registered in one municipality but performed their activities in another.

The survey was carried out by mail during the period from May to June $2010 .^{2}$ The survey was administered by the survey company Synovate. It was directed to the organizations and was completed by officials (chairs, treasurers, secretaries, and other members of the governing boards) of the voluntary associations. The survey

\footnotetext{
${ }^{1}$ Previous studies have argued that the register likely provides better coverage of large than small voluntary associations. For the purposes of this study, the register covers the population of voluntary associations sufficiently well.

2 In September 2010, local and national elections were held that altered the political landscape of two of the municipalities surveyed here. In the municipality of Katrineholm, the dominant Social Democratic party entered a coalition with the Moderate party, but remained four seats short of a majority in the municipal council. In the municipality of Berg, the dominant local party lost a large proportion of votes, weakening its position within the local governing coalition.
} 
sample totaled 800 associations, with $127^{3}$ organizations excluded from the sample as they were no longer active or did not have a valid address. A total of 404 voluntary associations responded to the postal survey, for a net response rate of approximately $60 \% .^{4}$ First, a short description of the surveyed population of associations is presented, along with a description of how they were categorized into leisure, interest, and activist organizations, followed by an analysis of the survey data. The organizations' categories were compared using t tests and chi-square tests (where applicable).

\section{Variables}

The number of members reported by the voluntary associations is logarithmic (ln) transformed, because of relatively large differences between the largest and the smallest organization, in order to reduce heteroskedasticity.

Several different items are used to measure the civic engagement, and an index was calculated to describe the strength of civic engagement. The strength of civic engagement was calculated as an additive index composed of the following items each rated on a 5-point Likert scale: it is important or unimportant for the association to be visible in the local community; it is important or unimportant for the association to contribute to the development of the local community; it is important or unimportant for the association to collaborate with other local associations; and it is important or unimportant for the association to contribute to the development of the local community. The index ranged from 0 to 20 , and Cronbach's alpha of the additive index was 0.86 .

The frequency of contact with local politicians was coded as follows: $1=$ never, $2=$ less often than once a year, $3=$ at least once a year, $4=$ every six months, $5=$ monthly. Furthermore, the heterogeneity of local government was coded from 1 to 4 where: 1 = one party local government; $2=$ small coalition with two parties; $3=$ coalition with three parties; $4=$ broad coalition with more than three parties.

The dependent variable perceived success from contacts with local-level politicians was coded as follows: $1=$ never successful, $2=$ seldom successful, $3=$ often successful, $4=$ always successful.

\section{Results}

Description of the Respondent Voluntary Associations

The Table 1 shows the types of voluntary association that responded to the survey. Although it is difficult to obtain exact estimates of the distribution of voluntary

\footnotetext{
3 Other studies using information from the register have found a similar proportion of ineligible organizations (see Lindberg 2005).

${ }^{4}$ Calculated as [received responses/(total sample - ineligibles $\left.)\right] \times 100=[404 /(800-127)] \times 100=$ $60.03 \%$.
} 
Table 1 Distribution of responding voluntary associations

\begin{tabular}{lc}
\hline Type of association & $\begin{array}{c}\text { Number (percentage of } \\
\text { responding voluntary } \\
\text { associations) }\end{array}$ \\
\hline Sports association & $71(17.6)$ \\
Home-related (home owners or tenants) & $4(1.0)$ \\
Religious congregation & $16(4.0)$ \\
Neighborhood association (or similar) & $20(5.0)$ \\
Cultural association & $53(13.1)$ \\
Trade union & $18(4.5)$ \\
Adult education & $4(1.0)$ \\
Parents' school association & $2(0.5)$ \\
Pensioners' association & $19(4.7)$ \\
Immigrants' association & $9(2.2)$ \\
Disabled or patients' association & $26(6.4)$ \\
Environmental organization & $5(1.2)$ \\
Local history association & $32(7.9)$ \\
Temperance organization & $5(1.2)$ \\
Charity/help organization & $11(2.7)$ \\
Hobby association & $27(6.7)$ \\
Hunting and fishing & $15(3.7)$ \\
Motor sports or car owners & $13(3.2)$ \\
Entrepreneurs' association & $9(2.2)$ \\
Fellowships & $6(1.5)$ \\
Fssociations for a common/road & $9(2.2)$ \\
Others & $5(1.2)$ \\
& $22(5.4)$ \\
\hline & \\
Sum & \\
&
\end{tabular}

associations among these sectors at the national level, the distribution in this study was similar to other estimates (Lundström and Svedberg 2003).

The Table 1 shows that sports associations constitute the largest proportion of respondents, along with cultural associations. Other population surveys on voluntary association involvement have shown that these types of voluntary association (cultural and sports associations) also tend to have the largest proportion of active members (Statistics Sweden 2011; Svedberg et al. 2010). Local history associations (hembygdsföreningar) may be slightly overrepresented from a national perspective, given that the sample contained two rural municipalities.

In hypothesis 1 , it was stated that the voluntary associations will tend to resemble each other, independent of activity, in how they try to influence politics within the same institutional frame work. In order to test whether the voluntary associations varied according to activity the same classification approach was adopted as in the study of van der Meer and van Ingen (2009), we classified the voluntary associations into three subgroups. However, because the number of activist groups was small, the 
activist and interest group categories were combined into a single category. ${ }^{5}$ Classification according to categories was based on the self-reported main activity of the surveyed associations. The main purpose of this classification was to compare so-called leisure organizations with activist or interest group organizations. Interest group organizations are narrower than activist organizations in terms of their scope, with a trade union being a typical example. In contrast, activist organizations have a broader scope and a less narrowly defined subject of interest, with environmental organizations being a typical example (cf. van der Meer and van Ingen 2009). For the sake of comparison (see van der Meer and van Ingen 2009), religious congregations, schools, and the category "other" were excluded from the analysis. See Table 2 for the coding scheme and the distribution of the associations among the categories.

\section{Voluntary Associations: Their Views on Their Roles in the Local Community}

How do voluntary associations view their roles in the local community? The survey provided a set of statements where the respondents' should place themselves according to a 5-point scale. The Table 3 displays the mean values for the various items and compares the mean values of the two categories of associations with $t$ tests.

Virtually, no differences were observed between the two categories of organizations in terms of their view of their roles in the local community, except for the item regarding taking part in meetings regarding the local community, which interest/activist groups found to be slightly more important (see Table 3).

\section{Contacts with Local Politicians}

One of the purposes of this study was to investigate the extent to which voluntary associations attempted to influence policy by directly contacting local politicians. Do leisure associations also frequently contact politicians, given the Swedish institutional context? Not surprisingly, the survey (see Table 4) found that a larger proportion of the interest/activist groups contacted local politicians. Notably, leisure groups contacted local politicians quite frequently as well, with approximately $43 \%$ of leisure organizations reporting having contacted local political representatives during the past 12 months, compared with $56 \%$ of the interest/activist associations. ${ }^{6}$ However, leisure groups tended to contact local politicians more frequently than interest/activist organizations. Hypothesis 1 (H1) can thus only be partially confirmed. Furthermore, the results also showed no statistically significant differences between the four municipalities in terms of the proportions of voluntary

\footnotetext{
${ }^{5}$ Different types of classification have been proposed by different studies (see Wijkström, 2010). We acknowledge the difficulty of classifying organizations. One example from Sweden is how the Swedish Association for Hunting and Wildlife Management organizes people with a common hobby (leisure); yet, they act as an interest group by advocating the legalization of hunting of wolves in Sweden (interest group).

6 The survey was conducted during an election year, but was administered before the most intense electoral campaigning began.
} 
Table 2 Classification of voluntary associations into different categories

\begin{tabular}{|c|c|c|}
\hline Type of association & Three categories & Two categories \\
\hline Sports association & Leisure & Leisure \\
\hline Home-related (home owners or tenants) & Interest & Interest \\
\hline Neighborhood association (or similar) & Interest & Interest \\
\hline Cultural association & Leisure & Leisure \\
\hline Trade union & Interest & Interest/activist \\
\hline Adult education & Leisure & Leisure \\
\hline Parents' school association & Interest & Interest/activist \\
\hline Pensioners' association & Interest & Interest/activist \\
\hline Immigrants' association & Interest & Interest/activist \\
\hline Disabled or patients' association & Interest & Interest \\
\hline Environmental organization & Activist & Interest/activist \\
\hline Local history association & Leisure & Leisure \\
\hline Temperance organization & Activist & Interest/activist \\
\hline Charity/help organization & Activist & Interest/activist \\
\hline Hobby association & Leisure & Leisure \\
\hline Hunting and fishing & Leisure & Leisure \\
\hline Motor sports or car owners & Leisure & Leisure \\
\hline Entrepreneurs' association & Interest & Interest \\
\hline Fellowships & Interest & Interest \\
\hline Associations for a common/road & Interest & Interest \\
\hline Farmers' association & Interest & Interest \\
\hline \multirow[t]{3}{*}{ Sum of organizations in different categories } & Leisure $N=215$ & Leisure $N=215$ \\
\hline & Interest $N=127$ & Interest-/activist $N=148$ \\
\hline & Activist $N=21$ & \\
\hline
\end{tabular}

Table 3 Attitudes toward civic engagement among local voluntary associations, comparison between leisure and interest/activist organizations, independent samples $t$ test

\begin{tabular}{lll}
\hline & $\begin{array}{l}\text { Leisure } \\
\text { organization }\end{array}$ & $\begin{array}{l}\text { Interest/ } \\
\text { activist }\end{array}$ \\
\hline Important to be visible in local community & 3.70 & 3.78 \\
Important to contribute to local development & 3.56 & 3.72 \\
Important to work with other associations in local community & 3.61 & 3.60 \\
Important to take part in meetings regarding the local community & 3.36 & 3.60 \\
\hline
\end{tabular}

$* p<0.05$; ** $p<0.01$, Legend: Coding of variables $1=$ not important at all, $5=$ very important

associations that reported contacting local politicians. The municipality-level averages range from 42 to 50 percent of associations having contacted local politicians in the past 12 months, with an overall average of 48 percent. $^{7}$ This

\footnotetext{
7 The reasons for contacting local politicians were: to address an issue important to the members of the association; to request financial support; address an issue regarding the local community; to request help to arrange events. The first three were by far the most frequently mentioned alternatives.
} 
Table 4 Contacts with local-level politicians, comparison between leisure and interest/activist organizations, independent samples $t$ test

\begin{tabular}{lll}
\hline & Leisure & Interest/activist \\
\hline Local politicians & $0.43^{*}$ & $0.56^{*}$ \\
Frequency of contacts with local-level politicians & 3.8 & 3.5 \\
Perceived success from contacts with local-level politicians & 2.11 & 2.14 \\
\hline
\end{tabular}

$* p<0.05 ; * * p<0.01$, Legend: Contact with local politicians: $1=100 \%$; Frequency of contact: $1=$ never, $2=$ less often than once a year, $3=$ at least once a year, $4=$ every six months, $5=$ monthly; Perceived success from contacts with local-level politicians: $1=$ never successful, $2=$ seldom successful, $3=$ often successful, $4=$ always successful

rate is similar to that found in previous surveys using national samples (Öberg and Svensson 2012). In the present data set, neither the size of the municipality nor the density of voluntary associations seem to have a significant impact on the frequency of contacts between voluntary associations and local politicians. However, these results remain tentative as the number of municipalities is small.

Furthermore, given the presumed higher levels of political skill among the interest and activist organizations, it was rather surprising that there was no statistically significant difference (Table 4) among the groups in terms of their perception of success from their contacts with local politicians.

\section{Multivariate Analysis}

A question that this study attempted to resolve was whether there are factors that determine the extent to which voluntary associations feel that local politicians are responsive to their requests. Here, regression analysis was applied using the perceived success rate from contacts as the dependent variable (for coding see methods section).

Three different explanatory models were constructed. The first model (Model I) in Table 5 contained only the characteristics of the voluntary associations in terms of their size (number of members) and behavior (the sum of different elite groups that had been contacted and how often contact with local politicians occurred). ${ }^{8}$ According to $\mathrm{H} 2 \mathrm{a}$, we would expect voluntary associations to perceive themselves as more successful the more often they contact local politicians. Furthermore, we would expect according to $\mathrm{H} 2 \mathrm{~b}$ that the more groups that have been contacted, the more likely it would be for the voluntary associations to perceive themselves as successful. According to H4, we would expect a positive impact of the number of members on the perceptions of success.

The second model (Model II) in (Table 5) addition to the characteristics of the voluntary associations in Model I also included a measure of the strength of the voluntary associations' civic engagement (H5). We would expect the strength of

\footnotetext{
${ }^{8}$ The type of voluntary associations is not included as it was not statistically significant in the previous bivariate analyses. Introducing the variable in the multivariate analyses does not alter the results and the variable is not significant.
} 
Table 5 Perceived success of contacts with local-level politicians as dependent variable, OLS regression

\begin{tabular}{lccc}
\hline & $\begin{array}{l}\text { Model I } \\
\text { unstandardized } \\
\text { coefficient }\end{array}$ & $\begin{array}{l}\text { Model II } \\
\text { unstandardized } \\
\text { coefficient }\end{array}$ & $\begin{array}{l}\text { Model III } \\
\text { unstandardized } \\
\text { coefficient }\end{array}$ \\
\hline Coefficient & $1.73^{*}$ & $2.10^{* *}$ & $2.00^{* *}$ \\
No. members (Ln) & -0.07 & -0.05 & -0.07 \\
Sum of different elite groups that have been & 0.2 & 0.03 & 0.03 \\
$\quad$ contacted & $0.21^{* *}$ & $0.19^{* *}$ & $0.16^{* *}$ \\
Frequency of contact & & $-0.04^{*}$ & $-0.03^{*}$ \\
$\begin{array}{l}\text { Strength of civic engagement } \\
\text { Heterogeneity of local government }\end{array}$ & & & $0.11^{*}$ \\
Contact with media & & $0.08 / 141$ & $0.13 / 141$ \\
$\mathrm{R}^{2}$ adjusted/N & $0.05 / 141$ & 0.08 & $0.21^{*}$ \\
\hline
\end{tabular}

$* p<0.05$; ** $p<0.01$; Legend: No. members: logarithmic (ln) transformed number of members; Sum of different elite groups that have been contacted: 0-3; Contact with local politicians: $1=100 \%$; Frequency of contact: $1=$ never, $2=$ less often than once a year, $3=$ at least once a year, $4=$ every six months, 5 = monthly; Perceived success from contacts with local-level politicians: $1=$ never successful, $2=$ seldom successful, 3 = often successful, 4 = always successful; Strength of civic engagement: 1-20; Heterogeneity of local government: $1=$ one party local government- $4=$ broad coalition with more than three parties; Contact with media: $1=$ yes, $0=$ no

civic engagement to have a negative impact on the perceptions of success by the local voluntary association in their contacts with local politicians according to H5.

The Model III (Table 5) also included the heterogeneity of the local government. According to $\mathrm{H} 2$, we would expect the voluntary associations to perceive themselves as more successful in their contacts with local politicians if the local government is composed by a coalition. The broader the coalition, that is, the more heterogeneous the local government is, the more likely it would be according to $\mathrm{H} 2$ for the voluntary associations to perceive that they are successful. A control variable of whether the voluntary associations had contacted the local media or not was introduced. Contact with local media is coded as a dummy variable where 1 equals have contacted media and 0 equals have not contacted local media on an issue regarding the voluntary association.

The results of Model I found that only the frequency of contact had a significant impact on the perception of local politicians' responsiveness (H2a). The number of different elite groups that had been contacted was not significant (H2b). Moreover, the hypothesis $(\mathrm{H} 4)$ of a positive effect of the number of members cannot be confirmed.

In Model II, the results show that the strength of the voluntary associations' civic engagement in the local community had a negative effect on their perceived success. This finding is in line with H5 and with previous qualitative studies from the Swedish local context (Nilsson 2005). The inclusion of this variable also slightly improved the model fit.

In Model III, the heterogeneity of the government variable was significant, implying that the broader the coalition became, the more likely it was for voluntary associations to perceive local-level politicians as responsive to their requests. This 
result is in line with $\mathrm{H} 3$. The impact of this variable was not strong, but this finding may have resulted from the limited number of municipalities included in the analysis. Contacts with the local media are introduced as a control variable and it is statistically significant. The results indicate that groups that contact local mass media are more successful than those that have not contacted local mass media. It confirms that media can together with the other factors mentioned above can contribute to creating more responsive local politicians.

\section{Discussion and Conclusions}

This study aimed to investigate two main questions. The first aim of the study was to investigate whether the associations contacted local-level politicians and, if so, whether there were any significant differences between different categories of them. Even though interest groups may be considered to have more political skill than leisure organizations, the study showed no significant difference in their perceived success. This finding may be tentatively interpreted as a result of these organizations being perceived as narrower interest groups by local politicians, whereas leisure organizations are perhaps less controversial and seen to represent broader groups within the local community.

The theoretical questions related to the roles played by local voluntary associations within local politics cover a broad range of issues. A general concern that has been expressed by scholars studying the changing role of civil society is how the civil society organizations have tended to turn away from politics (cf. Skocpol 2003). The present study shows that local voluntary associations in Sweden frequently contacted local politicians. The levels of contact measured in the present survey were similar to the findings of surveys conducted nearly a decade ago (Öberg and Svensson 2012). This result may be interpreted as showing that direct contacts have remained at a stable level over the past decade. However, the study does not investigate whether these local voluntary associations are detached from the national political arena or whether their interests remain purely local, as argued by Skocpol (2003).

It is important to underline how institutional differences among countries may also have affected the meaning of belonging to a certain category of association. Especially, in the context of what has been labeled as an input democracy with a strong focus on the input side of the policy process, as Sweden, we would expect associations to be actively trying to influence policy (cf. Goodin 2010). For instance, sports associations may be more prone to use the voice function in a Swedish institutional context than in a liberal context like the United States (cf. Salamon and Anheier 1998; Schofer and Fourcade-Gourinchas 2001; Lundström and Svedberg 2003; Wallman Lundåsen 2012).

Among the factors inherent to the voluntary associations, the perceived responsiveness of local politicians was affected by how often the voluntary associations contacted local politicians, with more frequent contact associated with a greater perception of success. At least two different interpretations of this result are possible. The first is that contact had an additive effect, as hypothesized and in 
line with previous studies (Verba and Nie 1987; Wohlgemuth 2006). A second possible explanation, which could not be tested in the present survey, is that the relationship was endogenous, that is, those organizations that perceived themselves to be successful self-selected in contacting politicians more often than others. The levels of perceived responsiveness of the local politicians were also affected by the degree of civic engagement expressed by the voluntary associations. Greater commitment to values of civic engagement by voluntary associations made them somewhat less likely to find local politicians to be responsive. Engagement in itself may have made the associations more aware of the extent of problems that needed to be confronted, thereby generating frustration (Nilsson 2005). Furthermore, the perceived responsiveness of local politicians was not correlated with the size (in terms of the number of members) of the voluntary associations. Perhaps, contrary to common belief, relatively large associations did not seem to perceive significantly more responsiveness to their demands than small organizations, in contrast to previous findings at the national level (Feltenius 2004). This could also be due to the nature of the issues raised by the larger associations. These issues may be larger and more difficult for the local communities to accommodate in a prompt manner, such as demands to build a new sports arena.

At the structural level, the results indicated a significant difference between the voluntary associations located within municipalities governed by coalitions and those within municipalities dominated by a single political party. These results seem to support the hypothesis of centrifugal behavior of the political parties within coalitions. A more fragmented elite political class seemed to provide more opportunities for local voluntary associations to perceive responsiveness. It is also possible to interpret this finding, tentatively, as demonstrating that coalitions were more vulnerable or open to pressure from outside groups because of the different levels of negotiation transpiring within the parties of the coalition and with groups external to it (cf. Morales 2009). To achieve a competitive advantage through improved public opinion and public support, a member of a governing coalition may have felt more tempted to support propositions from local voluntary associations. Moreover, in municipalities governed by coalitions, the voluntary associations may have several different political parties to approach to gain support for their requests. If one party turns down the requests, the association could approach the other parties of the coalition. These results also imply that voluntary associations with the same properties may have perceived varying degrees of success depending upon the composition of the local political elites. The responsiveness of the local politicians may depend upon the composition of the local government. Local governments that are composed of only a single party or a small coalition would consequently have less centrifugal behavior and feel less pressure to respond to a multitude of requests from local voluntary associations. The results also show that reporting in local mass media may increase the likelihood of local politicians being responsive to demands. The attention from local mass media may create a public debate regarding the issue and increase the pressure on the local politicians to listen to the demands of the voluntary associations. The heterogeneity of the (local) government is a factor that possibly can contribute to explain the perceived success of civil society 
organizations in different institutional settings as suggested in the social movement literature.

However, these findings require further testing with a larger set of municipalities to test the generalizability of this hypothesis, given the limited number of municipalities included in this study. Other questions that are important to address in future studies are how much responsiveness that actually is desirable within a local community, and whether certain groups have politicians listening more to them than to others.

In summary, the perceptions of having a more responsive local democracy seem to be explained by a complex mix of both factors inherent to the voluntary associations themselves and factors connected to the composition of the local governments. These findings suggest that, to obtain a better understanding of the role of voluntary associations within the local political process, both types of factors must be taken into consideration.

Acknowledgment I would like to thank the anonymous reviewers for helpful suggestions.

\section{Appendix}

See Table 6.

Table 6 Selection criteria for the municipalities

\begin{tabular}{lllll}
\hline & Sundbyberg & Katrineholm & Vadstena & Berg \\
\hline Population size & Average & Average & Small & Small \\
Associational density & Low & High & Low & High \\
$\begin{array}{l}\text { Local government at the time for survey } \\
\text { Left }\end{array}$ & Left & $\begin{array}{c}\text { Small coalition } \\
\text { (left/right) }\end{array}$ & Right \\
$\begin{array}{l}\text { Balanced scale of view on participatory/ } \\
\text { direct democracy }\end{array}$ & Negative & Negative & $\begin{array}{c}\text { Moderately } \\
\text { negative }\end{array}$ & Very \\
\end{tabular}

Source Statistics Sweden: official statistics, register of voluntary associations; Survey toward local politicians (Gilljam et al. 2010)

\section{References}

Ahrne, G., \& Papakostas, A. (2006). Kollektivt handlande i rörelser och organisationer. In Å. Wettergren \& A. Jamison (Eds.), Sociala rörelser. Studentlitteratur: Lund.

Almond, G., \& Verba, S. (1963). The Civic Culture. Boston: Little, Brown and Company Ltd.

Amnå, E. (2005). Still a Trustworthy Ally?: Civil Society and Transformation of Scandinavian Democracy. Journal of Civil Society, 2(1), 1-20.

Back, P. E. (1967). Sammanslutningarnas roll i politiken 1870-1910. Skellefteå: Västerbottens tryckeri.

Bäck, H., Offerdal, A., Aars, J. (2005). Partikommunens uppgång och fall. In Marie Demker, Lars Svåsand (Eds.), Partiernas århundrade: Fempartimodellens uppgång och fall $i$ Norge och Sverige. Stockholm: Santérus.

Christensen, D. A. \& Aars, J. (2011). Hur det locale organisasjonslivet betydning for inbyggeres vurdering av lokalpolitiker?. In D. Wollebæk, \& S Bock Segaard (Eds.) Sosial kapital $i$ Norge. Oslo:Cappellen Damm Akademisk. 
Einarsson, S. (2012). The revitalization of a popular movement: Case study research from Sweden. VOLUNTAS: International Journal of Voluntary and Nonprofit Organizations, 22(4), 658-681.

Elvander, N. (1968). Intresseorganisationerna i dagens Sverige. Lund: CWK Gleerups Förlag.

Feltenius, D. (2004). En pluralistisk maktordning? Om pensionärsorganisationernas politiska inflytande. Umeå: Umeå universitet.

Gilljam, M., Karlsson, D., \& Sundell, A. (2010). Politik på hemmaplan. Stockholm: SKL Kommentus AB.

Gilljam, M., Persson, M., \& Karlsson, D. (2012). Representatives' attitudes toward citizen protests: The impact of ideology, parliamentary position and experiences. Legislative Studies Quarterly, 37(2), 251-268.

Goodin, R. (2010). Reflective Democracy. Oxford: Oxford University Press.

Harding, T. (2012). How to establish a study association: Isomorphic pressures on new CSOs entering a neo-corporative adult education field in Sweden. VOLUNTAS: International Journal of Voluntary and Nonprofit Organizations, 23, 182-203.

Johansson, F., Karlsson, D., Johansson, B., \& Norén-Bretzer, Y. (2007). Kommunstorlek och demokrati. Stockholm: SKL.

Kitschelt, H. (1986). Political opportunity structures and political protest: Anti-nuclear movements in four democracies. British Journal of Political Science, 16(01), 57-85.

Knoke, D. (2009). Playing well together: Creating corporate social capital in strategic alliance networks. American Behavioral Scientist, 52(12), 1690-1708.

Lijphart, A. (1999). Patterns of democracy: Government forms and performance in thirty-six countries. New Haven: Yale University Press.

Lindberg, E. (2005). Vad kan medborgarna göra?. Stockholm: Almqvist \& Wicksell International.

Lundberg, E. (2012). Changing balance: The participation and role of voluntary organisations in the Swedish policy process. Scandinavian Political Studies, doi:10.1111/j.1467-9477.2012.00292.x.

Lundkvist, S. (1977). Folkrörelserna i det svenska samhället 1850-1920. Stockholm: Sober.

Lundström, T., \& Svedberg, L. (2003). The voluntary sector in a social democratic welfare state-the case of Sweden. Journal of Social Policy, 32(2), 217-238.

Maloney, W., \& van Deth, J (Eds.). (2010). Civil Society and activism in Europe: Contextualizing engagement and political orientations. London: Routledge.

McAdam, D. (1996). Conceptual Origins, Current Problems, Future Directions. In D. McAdam, J. McCarthy, M.N. Zald (Eds.) Comparative Perspectives on Social Movements. Political Opportunities, Mobillizing Structures, and Cultural Framings. New York: Cambridge University Press.

Micheletti, M. (1995). Civil Society and State Relations in Sweden. Avebury: Adlershot.

Morales, L. (2009). Joining political organizations. London: ECPR Press.

Munk Christiansen, P., Sonne Nørgard, A., Rommetvedt, H., Svensson, T., Thesen, G., \& Öberg, P. O. (2010). Varieties of Democracy: Interest Groups and Corporatist Committees in Scandinavian Policy Making. VOLUNTAS: International Journal of Voluntary and Nonprofit Organizations, 21(1), 22-40.

Nilsson, T (2005) Till vilken nytta? Lund: Lund University, 139, Dissertation.

Öberg, P. O., \& Svensson, T. (2012). Civil society and deliberative democracy: Have voluntary organisations faded from national public politics? Scandinavian Political Studies. doi:10.1111/j. 1467-9477.2012.00288.x.

Oxendine, A., Sullivan, J., Borgida, E., Riedel, E., Jackson, M., \& Dial, J. (2007). The importance of political context for understanding civic engagement: A longitudinal analysis. Political Behavior, $29(1), 31-67$.

Paxton, P. (2002). Social capital and democracy: an interdependent relationship. American Sociological Review, 67, 254-277.

Paxton, P. (2007). Association memberships and generalized trust: A multilevel model across 31 countries. Social Forces, 86(1), 47-76.

Putnam, R. (1993). Making democracy work. Princeton: Princeton University Press.

Putnam, R. (2000). Bowling alone. New York: Simon and Schuster.

Quintelier, E. (2008). Who is politically active: The athlete, the scout member or the environmental activist? Acta Sociologica, 51(4), 355-370.

Rochon, T. (1998). Culture moves: Ideas, activism, and changing values. Princeton: Princeton University Press.

Rothstein, B. (2005). Social traps and the problem of trust. Cambridge: Cambridge University Press. 
Salamon, L., \& Anheier, H. (1998). Social origins of civil society: Explaining the nonprofit sector crossnationally. VOLUNTAS: International Journal of Voluntary and Nonprofit Organizations, 9(3), 213-248.

Schofer, E., \& Fourcade-Gourinchas, M. (2001). The structural contexts of civic engagement: Voluntary association membership in comparative perspective. American Sociological Review, 66(6), $806-828$.

Schulz, T. (2010). Mobilizing Voluntary Work: The Interplay Between Organizations and Municipalities. In W. Maloney \& J. Van Deth (Eds.), Civil society and activism in Europe contextualizing engagement and political orientations. London: Routledge Research in Comparative Politics.

Schulz, T., \& Bailer, S. (2012). The impact of organisational attributes on political participation: results of a multi-level survey from Switzerland. Swiss Political Science Review, 18(1), 1-27.

Skocpol, T. (2003). Diminishing democracy: From membership to management in American civic life. Norman: Oklahoma University Press.

Statistics Sweden. (2011). The civil society-an assignment from the government with surveys from Statistics Sweden. Report, Statiscs Sweden: Örebro.

Stolle, D., (2001) "Getting to trust": An analysis of the importance of institutions, families, personal experiences and group membership, I Dekker, P and Uslaner, E (red), Social Capital and Participation in Everyday Life, London and New York: Routledge/ECPR.

Svedberg, L., von Essen, J., \& Jegermalm, M. (2010). Svenskarnas ideella engagemang är större än någonsin: Insatser $i$ och utanför föreningslivet. Stockholm: Enheten för forskning om det civila samhället, Ersta Sköndal Högskola, Report to the Government of Sweden.

Tarrow, S. (1998). Power in Movement: Social Movements and Contentious Politics. (Second revised edition ed.). New York: Cambridge University Press.

Teorell, J. (2003). Linking social capital to political participation: Voluntary associations and networks of recruitment. Scandinavian Political Studies, 26(1), 49-66.

Teorell, J. (2006). Political participation and three theories of democracy: A research inventory and agenda. European Journal of Political Research, 45, 787-810.

Trägårdh, L., \& Rothstein, B. (2007). The state and civil society in an historical perspective: The Swedish case. In L. Trägårdh (Ed.), State and civil society in Northern Europe. New York: Berghahn Books.

Van der Meer, T., \& van Ingen, E. (2009). Schools of democracy? Disentangling the relationship between civic participation and political action in 17 European countries. European Journal of Political Research., 48(2), 281-308.

Varda, D. (2012). A Network Perspective on State-Society Syngergy to Increase Community-Level Social Capital. Nonprofit and Voluntary Sector Quarterly, 40(5), 896-923.

Verba, S., \& Nie, N. (1972). Participation in America: Political Democracy and Social Equality. New York: Harper and Row.

Verba, S., \& Nie, H. (1987). Participation in America: Political Democracy and Social Equality. Chicago: The University of Chicago Press, Reprint.

Verba, S., Lehman Schlozman, K., \& Brady, H. (1995). Voice and Equality: Civic Voluntarism in American Politics. Cambridge: Harvard University Press.

Wallman Lundåsen, S. (2012). Debating future harmonization of European Union VAT regulations: Protests among Swedish nonprofit organizations. Nonprofit Policy Forum. doi:10.1515/2154-3348. 1041.

Wohlgemuth, D. (2006). Den responsiva demokratin?: effekter av medborgarnas delaktighet $i$ den lokala demokratin. Uppsala: Acta universitatis upsaliensis. Dissertation.

Wollebæk, D and Strømsnes, K (2008) Voluntary Associations, Trust, and Civic Engagement: A Multilevel Approach, Nonprofit and Voluntary Sector Quarterly, 37(2), 249-263.

Young, D. (2002). The influence of business on nonprofit organizations and the complexity of nonprofit accountability. American Review of Public Administration, 32(1): 3-19.

Zald, M. N., \& Ash, R. (1966). Social movement organizations: Growth, decline, and change. Social Forces, 44, 327-340. 